\title{
Airbrush Spray Coating of Amorphous Titanium Dioxide for Inverted Polymer Solar Cells
}

\author{
Luca La Notte, Luigi Salamandra, Andrea Zampetti, Francesca Brunetti, Thomas M. Brown, \\ Aldo Di Carlo, and Andrea Reale
} Department of Electronic Engineering, (Centre for Hybrid and Organic Solar Energy), CHOSE, University of Rome Tor Vergata,
Via del Politecnico 1, 00133 Rome, Italy

Correspondence should be addressed to Andrea Reale, reale@uniroma2.it

Received 25 September 2012; Revised 17 October 2012; Accepted 18 October 2012

Academic Editor: Vincenzo Augugliaro

Copyright () 2012 Luca La Notte et al. This is an open access article distributed under the Creative Commons Attribution License, which permits unrestricted use, distribution, and reproduction in any medium, provided the original work is properly cited.

One of the main topics of organic photovoltaics manufacturing is the need for simple, low cost, and large area compatible techniques. Solution-based processes are the best candidates to achieve this aim. Among these, airbrush spray coating has successfully applied to deposit both active and PEDOT layers of bulk-heterojunction solar cells. However, this technique is not yet sufficiently studied for interfacial layers (electron and hole transporting layers or optical spacers). In this paper, we show that amorphous titanium dioxide $\left(\mathrm{TiO}_{x}\right)$ films, obtained with an airbrush from a solution of titanium (IV) isopropoxide diluted in isopropanol, are successfully deposited on glass and PET substrates. Good surface covering results from the coalescence of droplets after optimizing the spray coating system. Simple inverted polymer solar cells are fabricated using $\mathrm{TiO}_{x}$ as electron transporting layer obtaining encouraging electrical performances $(\eta=1.54 \%$ on glass/FTO and $0.7 \%$ on PET/ITO substrates).

\section{Introduction}

During the last years, much efforts have been spent in the field of organic photovoltaics (OPV), the most promising technology for solar energy harvesting with reduced energy payback time [1] and high power to weight ratio [2], which is able to ensure large-scale manufacture at low cost. In particular, polymer solar cells (PSCs) are extensively studied for the simplicity of processing and the opportunity to realize lightweight and flexible devices. As reported in the literature, an inverted architecture of PSCs facilitates the realization of semitransparent devices $[3,4]$, with higher photocurrent [5], reaching good operational stability [6], and overcoming some problems of the conventional structure, like detrimental interaction at ITO/PEDOT interface [7] or rapid oxidation of the low-work-function metal of the electrode [8]. Inorganic $n$-type semiconductors, such as titanium dioxide $\left(\mathrm{TiO}_{2}\right)$, zinc oxide $(\mathrm{ZnO})$, and cesium carbonate $\left(\mathrm{Cs}_{2} \mathrm{CO}_{3}\right)$, are usually used as electron transporting layer (ETL) in inverted PSCs, due to their large band gaps and the good electron extraction property. Although $\mathrm{Cs}_{2} \mathrm{CO}_{3}$ has demonstrated to be a valid ETL for high efficiency devices $[9,10]$, its use involves the handling of hazardous solvents. In this work, we, therefore, prefer $\mathrm{TiO}_{2}$ whose preparation is simpler and safer. $\mathrm{TiO}_{2}$ films can be deposited by different techniques [11-13], but very few of them allow to process films at low temperatures $\left(<150^{\circ} \mathrm{C}\right)$, compatible with plastic substrates. At this condition, titanium dioxide is generally in amorphous phase $\left(\mathrm{TiO}_{x}\right)$, and it can be realized by solution methodologies as spin coating [14], electrodeposition [15, 16], and chemical bath [17]. Spray deposition is a simple, low cost, and large area compatible technique that is already successfully applied to PSCs to realize the active layer [18, 19], PEDOT [20, 21], and some ETLs [10, 22], but not yet applied to $\mathrm{TiO}_{x}$ for low temperature processing over plastic substrates. We investigate the use of airbrushing in order to realize amorphous titanium dioxide thin film as electron transporting layer for inverted polymer solar cells on glass and plastic substrates. 


\section{Experimental Details}

The photovoltaic devices were realized on FTO-coated glass substrate (Pilkington, $\sim 8 \Omega / \square$ ) and on PET foils coated with a transparent conductive ITO/Ag/ITO multilayer (PET/DMD, Solutia, $\sim 8 \Omega / \square$ ). Glass/FTO substrates were patterned by wet etching using chloridric acid $(3 \mathrm{M})$ and zinc powder [23] and cleaned by ultrasonic bath with acetone and isopropyl alcohol (15 min each step); PET/DMD foils were etched by immersion in bromidric acid and then cleaned by ultrasonic bath with isopropyl alcohol for $15 \mathrm{~min}$.

Amorphous titanium dioxide $\left(\mathrm{TiO}_{x}\right)$ was deposited by spraying a solution of the precursor titanium (IV) isopropoxide 5\% (v/v) (Sigma-Aldrich) in isopropyl alcohol by a dual action commercial airbrush (Mecafer) supplied by compressed air. The process was carried out in conventional environment (air) under chemical hood. The active layer is a P3HT (Rieke Metal) and PCBM (Solenne BV) blend ( $1: 0.7)$ dissolved in ortho-dichlorobenzene (o-DCB) at $2 \mathrm{wt} \%$ and stirred on a hot plate at $70^{\circ} \mathrm{C}$ for $24 \mathrm{~h}$. It was spin coated in a glove box at $900 \mathrm{rpm}$ for $60 \mathrm{~s}$ and then dried by slow evaporation in nitrogen atmosphere.

Two materials were used as hole transporting layer (HTL): (i) PEDOT (VPAI4083, Clevios) mixed with Triton$\mathrm{X}$ surfactant at $1 \mathrm{wt} \%$ (to improve the wettability on hydrophobic layers), was spin coated at $3000 \mathrm{rpm}$ for $60 \mathrm{~s}$ and annealed at $140^{\circ} \mathrm{C}$ for $10 \mathrm{~min}$ and (ii) molybdenum oxide $\left(\mathrm{MoO}_{3}\right)$ was evaporated on active layer in high vacuum $\left(10^{-6} \mathrm{~m}\right.$ bar) at $0.2 \AA / \mathrm{s}$. Finally, a silver layer of $100 \mathrm{~nm}$ was thermally evaporated as electrode in high vacuum at $1 \AA / \mathrm{s}$. A shadow mask was used in order to define the active area of the solar cells, equal to $7 * 7 \mathrm{~mm}^{2}$.

The thickness of the as-deposited films was measured with a profilometer (Dektak 150); optical images and transmittances of $\mathrm{TiO}_{x}$ films were acquired by a microscope (LEXT OLS4000) and a UV-VIS-NIR spectrophotometer (Shimadzu UV2550), respectively.

The morphology of $\mathrm{TiO}_{x}$ surface was analyzed by scanning electron microscopy (SEM, JEOL JSM-6010LA) and the crystalline phase of the layers was investigated using a HORIBA micro-Raman system (LabRAM ARAMIS) equipped with $\mathrm{Ar}^{+}$ion laser $(514.5 \mathrm{~nm}$ ) as excitation source.

Electrical performance of the devices was evaluated outside the glove box under a solar simulator KHS Solar Constant 1200 AM1.5 Class B $\left(100 \mathrm{~mW} / \mathrm{cm}^{2}\right)$ with a parameter analyzer (Agilent E5291A); for the measurements, we used a shadow mask to avoid performance contributions outside the active area [24]. Before each measurement, the irradiation level at the quote and position of the solar cell was verified by a means of a calibrated pyranometer (Skye SKS1110). All the samples were measured unsealed.

\section{Results and Discussion}

A preliminary investigation was carried out in order to find the highest possible temperature to hold plastic substrates during the spray deposition. According to our previous work [25], mechanical and optical characteristics of PET foils are preserved until $\sim 150^{\circ} \mathrm{C}$; therefore, this temperature was chosen and applied to our process as not damaging for PET substrates.

Different parameters of the airbrush spray process were varied in specific ranges to find the optimized conditions for a uniform and homogeneous deposition of $\mathrm{TiO}_{x}$ films on glass/FTO substrates: air compressed pressure (1-2 bar), precursor solution concentration $(1 \%-5 \%)$, airbrush distance from substrate $(10-30 \mathrm{~cm})$, and spray nozzle outlet. Uniformity of $\mathrm{TiO}_{x}$ deposition was checked by optical microscopy. The optical images in Figure 1 represent the effect of precursor concentration $(1,2$, and $5 \% \mathrm{v} / \mathrm{v})$, the parameter that most affects the $\mathrm{TiO}_{x}$ droplets deposition. The solid content of $\mathrm{TiO}_{x}$ is limited to ring-shaped droplets for low concentrations ( 1 and $2 \% \mathrm{v} / \mathrm{v})$ and fills the entire droplet areas for $5 \% \mathrm{v} / \mathrm{v}$ concentration, allowing a better surface covering; larger concentrations make the process difficult because of the hydrolysis and polycondensation of precursor which occur directly in the solution phase.

Figure 1(c) is an example of good uniformity; although uncovered areas are evident, the deposition is an acceptable compromise because further sprays cause the generation of $\mathrm{TiO}_{x}$ white powder (Figure $1(\mathrm{~d})$ ). The image also reveals the possible mechanisms of $\mathrm{TiO}_{x}$ formation; sprayed droplets reach the heated substrate where they undergo solvent evaporation and solute hydrolysis, so that the surface is covered by condensed $\mathrm{TiO}_{x}$ droplets.

A deeper structural and optical investigation was performed on the sample shown in Figure 1(c). Scanning Electron Microscope (SEM) analysis of the surface (Figure 2) confirms the results obtained by optical microscopy; $\mathrm{TiO}_{x}$ is made of droplets of various dimensions, not uniformly distributed on the substrate which superimpose and coalesce, leaving some areas uncovered.

Moreover, Raman spectroscopy reveals the amorphous nature of the film (Figure 3), as expected for the low operational temperature $\left(150^{\circ} \mathrm{C}\right)$, not sufficient for the crystallization of the material. For comparison, a titanium dioxide film was deposited at $450^{\circ} \mathrm{C}$ in the same conditions and the typical peaks associated to anatase phase $(142,400,514$, and $635 \mathrm{~cm}^{-1}$ ) are observed in the corresponding spectrum.

Figure 4 shows the transmittance of $\mathrm{TiO}_{x}$ film deposited on glass/FTO. The layer does not seem to influence the transmittance of the pristine substrate; a slight mismatch is evident only at high wavelengths because of the major absorption of $\mathrm{TiO}_{x}$ [26]. The thickness of $\mathrm{TiO}_{x}$ layer results to be $\sim 50 \mathrm{~nm}$ as measured at the profilometer.

Inverted solar cells were fabricated on glass/FTO substrates (inset of Figure 5). Optimized parameters were used for the realization of $\mathrm{TiO}_{x}$ layer: air compressed pressure (1.5 bar), precursor solution concentration $(5 \% \mathrm{v} / \mathrm{v})$, airbrush-substrate distance $(20 \mathrm{~cm})$, temperature substrate $\left(150^{\circ} \mathrm{C}\right)$ and intermediate spray nozzle outlet. The devices were completed with P3HT: PCBM active layer, PEDOT/ Triton-X as hole transporting layer, and silver anode. As a reference, a sample with a $\mathrm{TiO}_{x}$ layer spin-coated from the precursor and annealed at $150^{\circ} \mathrm{C}$ was also realized [27]. The $I-V$ curves of the solar cells are shown in Figure 5. The device behavior exhibits a strong dependence from the number of sprays in $\mathrm{TiO}_{x}$ deposition. The best results 
TABLE 1: Photovoltaic parameters of the device fabricated on glass/FTO and PET/DMD.

\begin{tabular}{|c|c|c|c|c|c|}
\hline Technique & Substrate & $V_{\mathrm{OC}}(\mathrm{mV})$ & $J_{\mathrm{SC}}\left(\mathrm{mA} / \mathrm{cm}^{2}\right)$ & FF (\%) & $\eta(\%)$ \\
\hline $\begin{array}{l}\text { Airbrush } \\
4 \text { sprays }\end{array}$ & glass/FTO & 568 & 6.3 & 42.9 & 1.54 \\
\hline $\begin{array}{l}\text { Airbrush } \\
6 \text { sprays }\end{array}$ & glass/FTO & 522 & 6.7 & 33.5 & 1.17 \\
\hline Spin coating & glass/FTO & 505 & 6.7 & 37.9 & 1.28 \\
\hline $\begin{array}{l}\text { Airbrush } \\
4 \text { sprays }\end{array}$ & PET/DMD & 491 & 3.6 & 35.8 & 0.63 \\
\hline
\end{tabular}
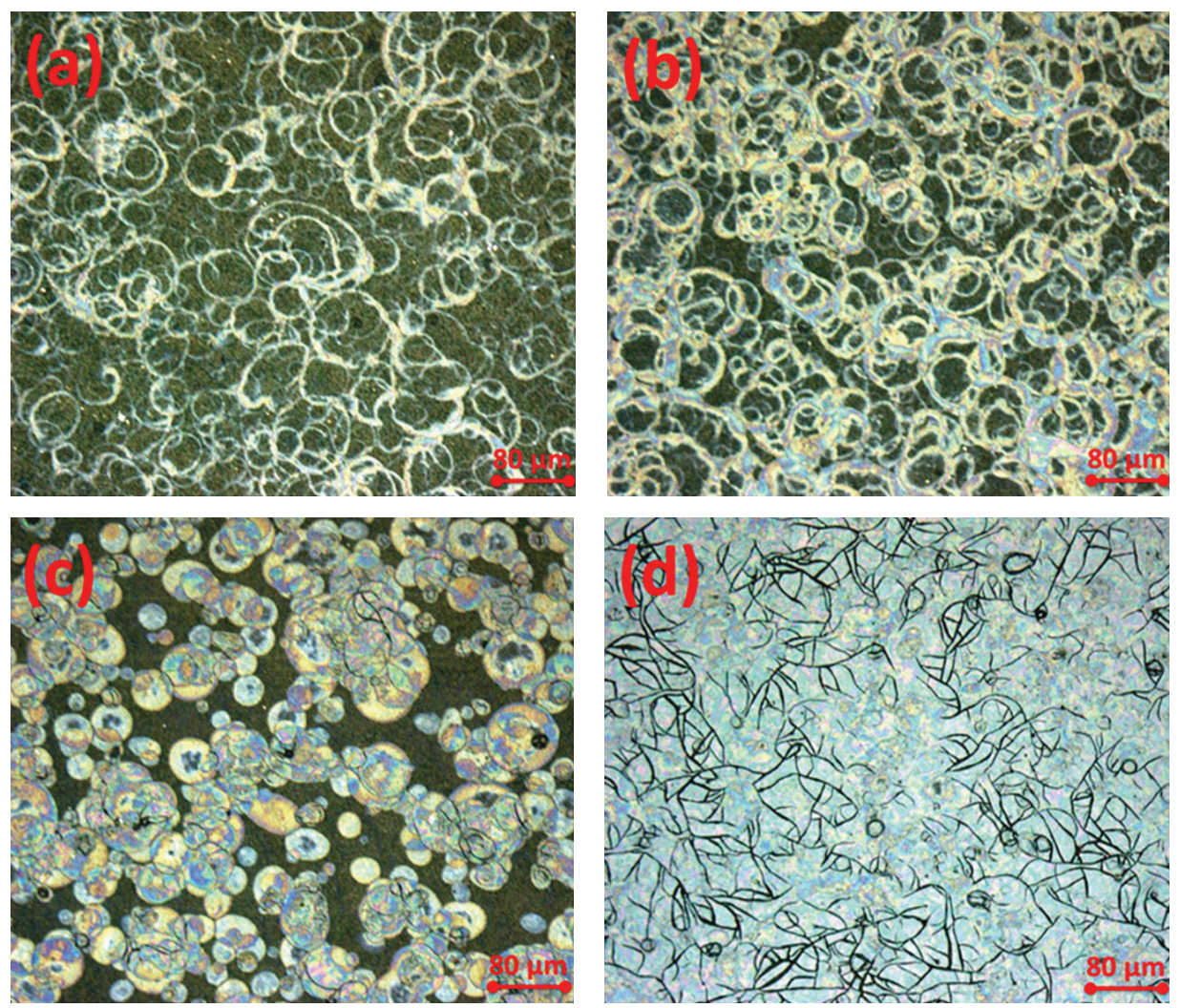

Figure 1: Optical images of $\mathrm{TiO}_{x}$ realized on glass/FTO substrate with 4 sprays at different TTIP concentration in 2-isopropanol: (a) 1\%, (b) $2 \%$, and (c) $5 \%$. In case of (d), that corresponds to a $5 \%$ concentration with 8 sprays, white powder formation is observed.

are reached with four and six sprays, demonstrating the feasibility of the spray deposition of $\mathrm{TiO}_{x}$ even at low temperatures. Relatively high values of $V_{\mathrm{OC}}$ prove the validity of the sprayed $\mathrm{TiO}_{x}$ film in terms of work function for a good electron injection; in addition, it has already been demonstrated that, in spite of its amorphous nature, $\mathrm{TiO}_{x}$ has an acceptable electron mobility, a well-defined energy gap $(3.7 \mathrm{eV})$, and a good charge selectivity $[28,29]$. Six sprays are enough to reproduce the results of the spin-coated solgel film. Moreover, with four sprays, we obtain an increase in the $V_{\mathrm{OC}}$ and FF, probably due to the reduced thickness of the $\mathrm{TiO}_{x}$ film that decreases the internal series resistance of the cell.

The detailed electrical characterization of the devices is summarized in Table 1. For samples realized with a number of $\mathrm{TiO}_{x}$ sprays out of the range 4-6, we did not observe any measurable photovoltaic activity.
The encouraging results obtained from devices on glass substrates suggested us to transfer the same process on plastic. Inverted solar cells were fabricated on PET/DMD foils spraying $\mathrm{TiO}_{x}$ at the conditions previously described. During the process, the foils were held on glass support by means of a repositionable adhesive ( $3 \mathrm{M}$ spray mount). The cells were completed with P3HT: PCBM active layer, $\mathrm{MoO}_{3}$ thin film $(3 \mathrm{~nm})$, and silver anode $(100 \mathrm{~nm})$. We chose to deposit evaporated $\mathrm{MoO}_{3}$ as a hole transporting layer to ensure a better conformation on the underlying blend and to prevent problems due to the hygroscopic nature of the PEDOT [27]. The preliminary results are reported on Table 1. Even if the photocurrent measured on plastic substrate is lower with respect to glass/FTO, we believe that these results demonstrate that it is worthy to focus on further optimization for possible upscale of the technique to largearea deposition of polymer solar cells. 


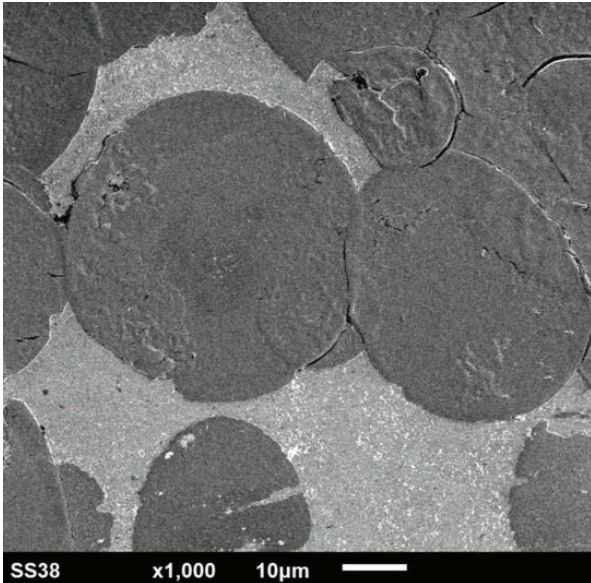

FIGURE 2: SEM surface image of sprayed $\mathrm{TiO}_{x}$ droplets on glass/FTO substrate.

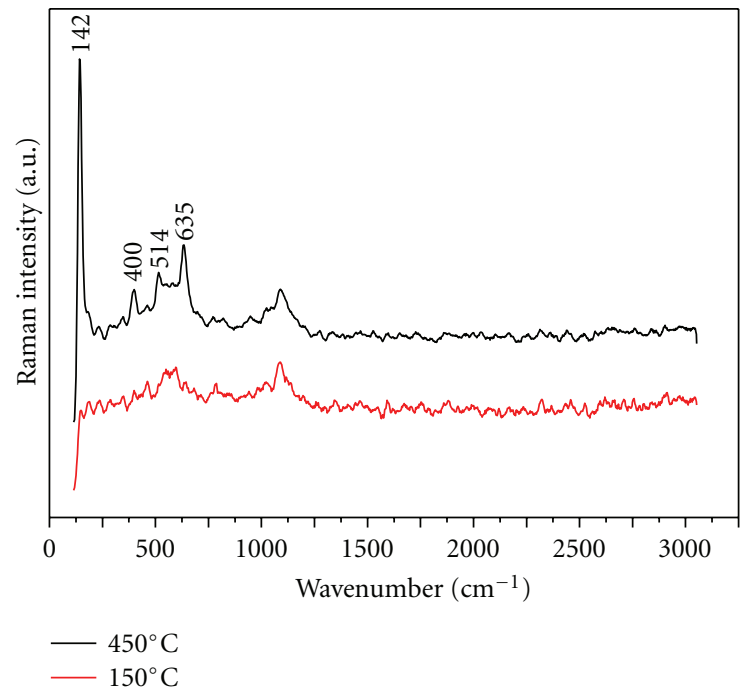

Figure 3: Raman spectra of titanium dioxide deposited on glass/FTO substrate at $150^{\circ} \mathrm{C}$ (amorphous phase) and $450^{\circ} \mathrm{C}$ (anatase phase). The peak at $1090 \mathrm{~cm}^{-1}$ (not indicated) identifies the substrate.

\section{Conclusions}

Airbrush spray coating was employed and optimized to deposit amorphous titanium dioxide $\left(\mathrm{TiO}_{x}\right)$ at low temperatures $\left(<150^{\circ} \mathrm{C}\right)$, compatible with plastic PET substrate. Optical and structural characterizations show a layer realized by overlap and coalescence of $\mathrm{TiO}_{x}$ droplets, with suitable features to be applied as electron transporting layer in inverted polymer solar cells. Glass/FTO/TiO ${ }_{x} /$ PCBM:P3HT/PEDOT/Ag devices were fabricated, and interesting results were obtained in terms of $V_{\mathrm{OC}}(568 \mathrm{mV})$ and overall efficiency $(1.54 \%)$. At the same spraying conditions, $\mathrm{PET} / \mathrm{DMD} / \mathrm{TiO}_{x} / \mathrm{PCBM}: \mathrm{P} 3 \mathrm{HT} / \mathrm{MoO}_{3} / \mathrm{Ag}$ devices were also realized; $V_{\mathrm{OC}}(491 \mathrm{mV})$ and efficiency $(0.63 \%)$ values are encouraging. We will perform further investigation to improve the electrical performance and achieve

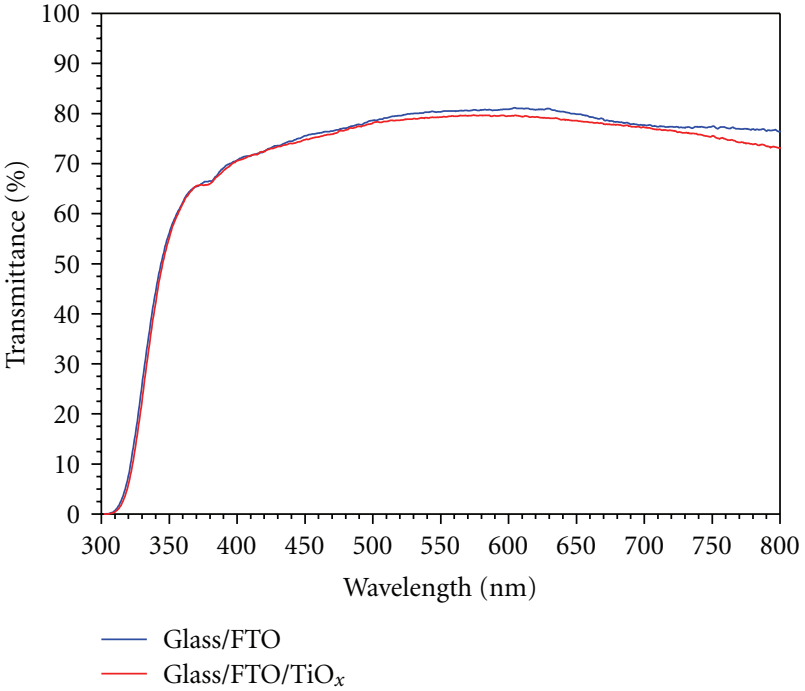

FIgURE 4: Transmittance of pristine glass/FTO (blue curve) and glass/FTO with the deposited $\mathrm{TiO}_{x}$ (red curve).

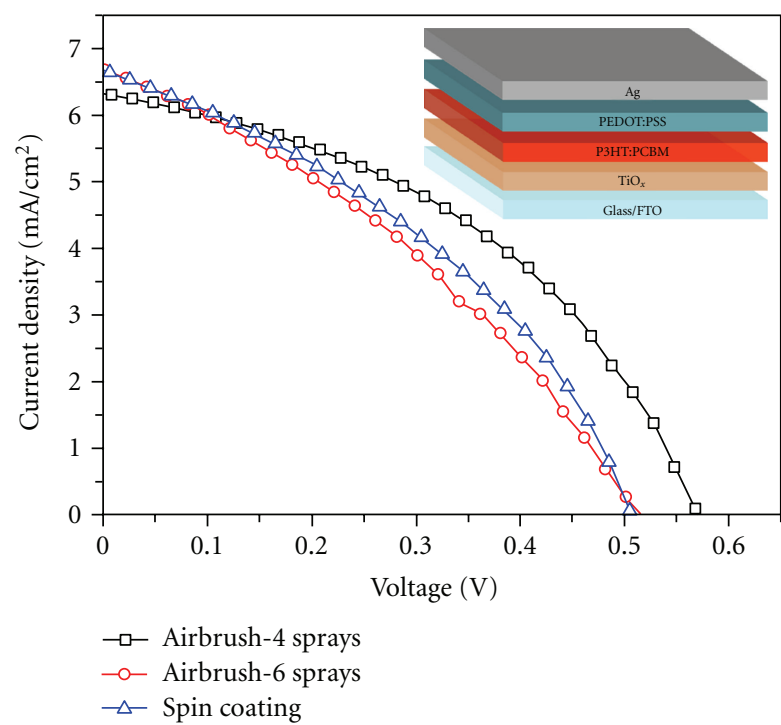

Figure 5: $J-V$ characteristics of a device with $\mathrm{TiO}_{x}$ deposited by airbrush 4 sprays $(\square)$ and airbrush 6 sprays $(\bigcirc)$ compared with a device with $\mathrm{TiO}_{x}$ realized by spin coating $(\triangle)$.

semitransparency. A sprayed $\mathrm{TiO}_{x}$ layer could be a boost in the perspective of the fabrication of a "fully sprayed" solar cell.

\section{Acknowledgments}

The authors wish to thank Antonio Agresti and Dr. Alessia Quatela for performing Raman spectroscopy measurements and for supporting in interpretation of the results. They acknowledge the support of the Regione Lazio through "Polo Solare Organico." 


\section{References}

[1] N. Espinosa, M. Hösel, D. Angmo, and F. C. Krebs, "Solar cells with one-day energy payback for the factories of the future," Energy and Environmental Science, vol. 5, no. 1, pp. 5117-5132, 2012.

[2] M. Kaltenbrunner, M. S. White, E. D. Głowacki et al., "Ultrathin and lightweight organic solar cells with high flexibility," Nature Communications, vol. 3, article 1772, p. 770, 2012.

[3] Y. Zhou, F. Li, S. Barrau, W. Tian, O. Inganäs, and F. Zhang, "Inverted and transparent polymer solar cells prepared with vacuum-free processing," Solar Energy Materials and Solar Cells, vol. 93, no. 4, pp. 497-500, 2009.

[4] A. Colsmann, M. Reinhard, T.-H. Kwon et al., "Inverted semitransparent organic solar cells with spray coated, surfactant free polymer top-electrodes," Solar Energy Materials and Solar Cells, vol. 98, pp. 118-123, 2012.

[5] S. Albrecht, S. Schäfer, I. Lange et al., "Light management in PCPDTBT:PC ${ }_{70}$ BM solar cells: a comparison of standard and inverted device structures," Organic Electronics, vol. 13, no. 4, pp. 615-622, 2012.

[6] H. Sun, J. Weickert, H. C. Hesse, and L. Schmidt-Mende, "UV light protection through $\mathrm{TiO}_{2}$ blocking layers for inverted organic solar cells," Solar Energy Materials and Solar Cells, vol. 95, no. 12, pp. 3450-3454, 2011.

[7] M. P. De Jong, L. J. Van Ijzendoorn, and M. J. A. De Voigt, "Stability of the interface between indium-tin-oxide and poly $(3,4$ ethylenedioxythiophene)/poly(styrenesulfonate) in polymer light-emitting diodes," Applied Physics Letters, vol. 77, no. 14, pp. 2255-2257, 2000.

[8] M. Jørgensen, K. Norrman, and F. C. Krebs, "Stability/degradation of polymer solar cells," Solar Energy Materials and Solar Cells, vol. 92, no. 7, pp. 686-714, 2008.

[9] H. H. Liao, L. M. Chen, Z. Xu, G. Li, and Y. Yang, "Highly efficient inverted polymer solar cell by low temperature annealing of $\mathrm{Cs}_{2} \mathrm{CO}_{3}$ interlayer," Applied Physics Letters, vol. 1, no. 4, Article ID 173303, 2008.

[10] J. E. Lewis, E. Lafalce, P. Toglia, and X. Jiang, "Over 30\% transparency large area inverted organic solar array by spray," Solar Energy Materials and Solar Cells, vol. 95, no. 10, pp. 2816-2822, 2011.

[11] P. S. Shinde, S. B. Sadale, P. S. Patil et al., "Properties of spray deposited titanium dioxide thin films and their application in photoelectrocatalysis," Solar Energy Materials and Solar Cells, vol. 92, no. 3, pp. 283-290, 2008.

[12] P. Baroch, J. Musil, J. Vlcek, K. H. Nam, and J. G. Han, "Reactive magnetron sputtering of $\mathrm{TiO}_{\mathrm{X}}$ films," Surface and Coatings Technology, vol. 193, no. 1-3, pp. 107-111, 2005.

[13] G. A. Battiston, R. Gerbasi, A. Gregori, M. Porchia, S. Cattarin, and G. A. Rizzi, "PECVD of amorphous $\mathrm{TiO}_{2}$ thin films: effect of growth temperature and plasma gas composition," Thin Solid Films, vol. 371, no. 1, pp. 126-131, 2000.

[14] I. Sasajima, S. Uesaka, T. Kuwabara, T. Yamaguchi, and K. Takahashi, "Flexible inverted polymer solar cells containing an amorphous titanium oxide electron collection electrode," Organic Electronics, vol. 12, no. 1, pp. 113-118, 2011.

[15] T. Kuwabara, H. Sugiyama, T. Yamaguchi, and K. Takahashi, "Inverted type bulk-heterojunction organic solar cell using electrodeposited titanium oxide thin films as electron collector electrode," Thin Solid Films, vol. 517, no. 13, pp. 3766-3769, 2009.

[16] S. Karuppuchamy and J. M. Jeong, "Super-hydrophilic amorphous titanium dioxide thin film deposited by cathodic electrodeposition," Materials Chemistry and Physics, vol. 93, no. 2-3, pp. 251-254, 2005.

[17] T. Kuwabara, H. Sugiyama, M. Kuzuba, T. Yamaguchi, and K. Takahashi, "Inverted bulk-heterojunction organic solar cell using chemical bath deposited titanium oxide as electron collection layer," Organic Electronics, vol. 11, no. 6, pp. 11361140, 2010.

[18] G. Susanna, L. Salamandra, T. M. Brown, A. Di Carlo, F. Brunetti, and A. Reale, "Airbrush spray-coating of polymer bulk-heterojunction solar cells," Solar Energy Materials and Solar Cells, vol. 95, no. 7, pp. 1775-1778, 2011.

[19] K. X. Steirer, M. O. Reese, B. L. Rupert et al., "Ultrasonic spray deposition for production of organic solar cells," Solar Energy Materials and Solar Cells, vol. 93, no. 4, pp. 447-453, 2009.

[20] J. Weickert, H. Sun, C. Palumbiny, H. C. Hesse, and L. Schmidt-Mende, "Spray-deposited PEDOT:PSS for inverted organic solar cells," Solar Energy Materials and Solar Cells, vol. 94, no. 12, pp. 2371-2374, 2010.

[21] K. J. Kim, Y. S. Kim, W. S. Kang et al., "Inspection of substrate-heated modified PEDOT:PSS morphology for all spray deposited organic photovoltaics," Solar Energy Materials and Solar Cells, vol. 94, no. 7, pp. 1303-1306, 2010.

[22] J.-W. Kang, Y.-J. Kang, S. Jung et al., "Fully spray-coated inverted organic solar cells," Solar Energy Materials and Solar Cells, vol. 103, pp. 76-79, 2012.

[23] G. Bradshaw and A. J. Hughes, "Etching methods for indium oxide/tin oxide films," Thin Solid Films, vol. 33, no. 2, pp. L5L8, 1976.

[24] S. Ito, M. K. Nazeeruddin, P. Liska et al., "Photovoltaic characterization of dye-sensitized solar cells: effect of device masking on conversion efficiency," Progress in Photovoltaics, vol. 14, no. 7, pp. 589-601, 2006.

[25] V. Zardetto, T. M. Brown, A. Reale, and A. Di Carlo, "Substrates for flexible electronics: a practical investigation on the electrical, film flexibility, optical, temperature, and solvent resistance properties," Journal of Polymer Science B, vol. 49, no. 9, pp. 638-648, 2011.

[26] G. Mincuzzi, M. Schulz-Ruhtenberg, L. Vesce et al., "Laser processing of $\mathrm{TiO}_{2}$ films for dye solar cells: a thermal, sintering, throughput and embodied energy investigation," Progress in Photovoltaics. In press.

[27] C. Y. Li, T. C. Wen, T. H. Lee et al., "An inverted polymer photovoltaic cell with increased air stability obtained by employing novel hole/electron collecting layers," Journal of Materials Chemistry, vol. 19, no. 11, pp. 1643-1647, 2009.

[28] J. Y. Kim, S. H. Kim, H. H. Lee et al., "New architecture for high-efficiency polymer photovoltaic cells using solutionbased titanium oxide as an optical spacer," Advanced Materials, vol. 18, no. 5, pp. 572-576, 2006.

[29] C. Waldauf, M. Morana, P. Denk et al., "Highly efficient inverted organic photovoltaics using solution based titanium oxide as electron selective contact," Applied Physics Letters, vol. 89, no. 23, Article ID 233517, 2006. 


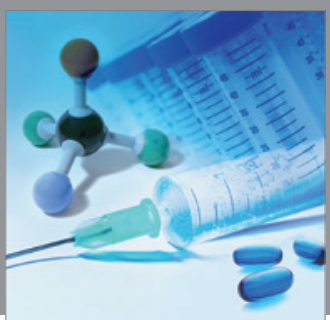

International Journal of

Medicinal Chemistry

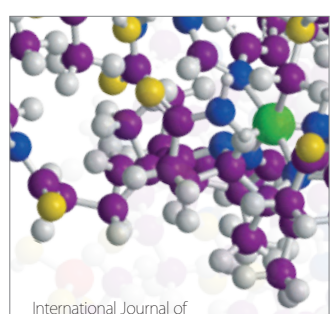

Carbohydrate Chemistry

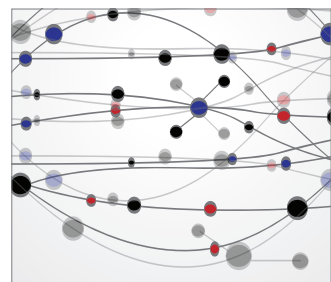

The Scientific World Journal
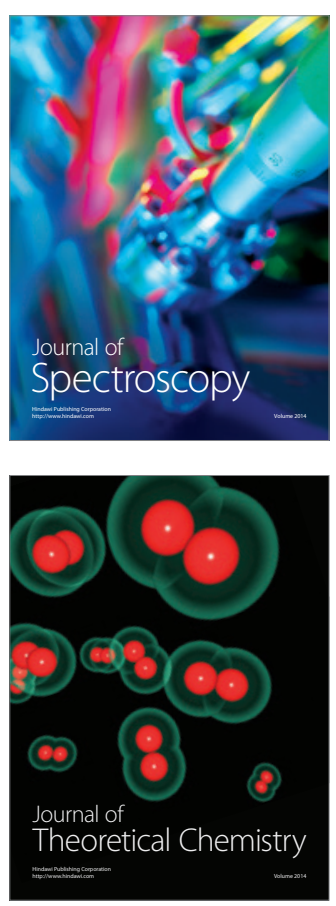
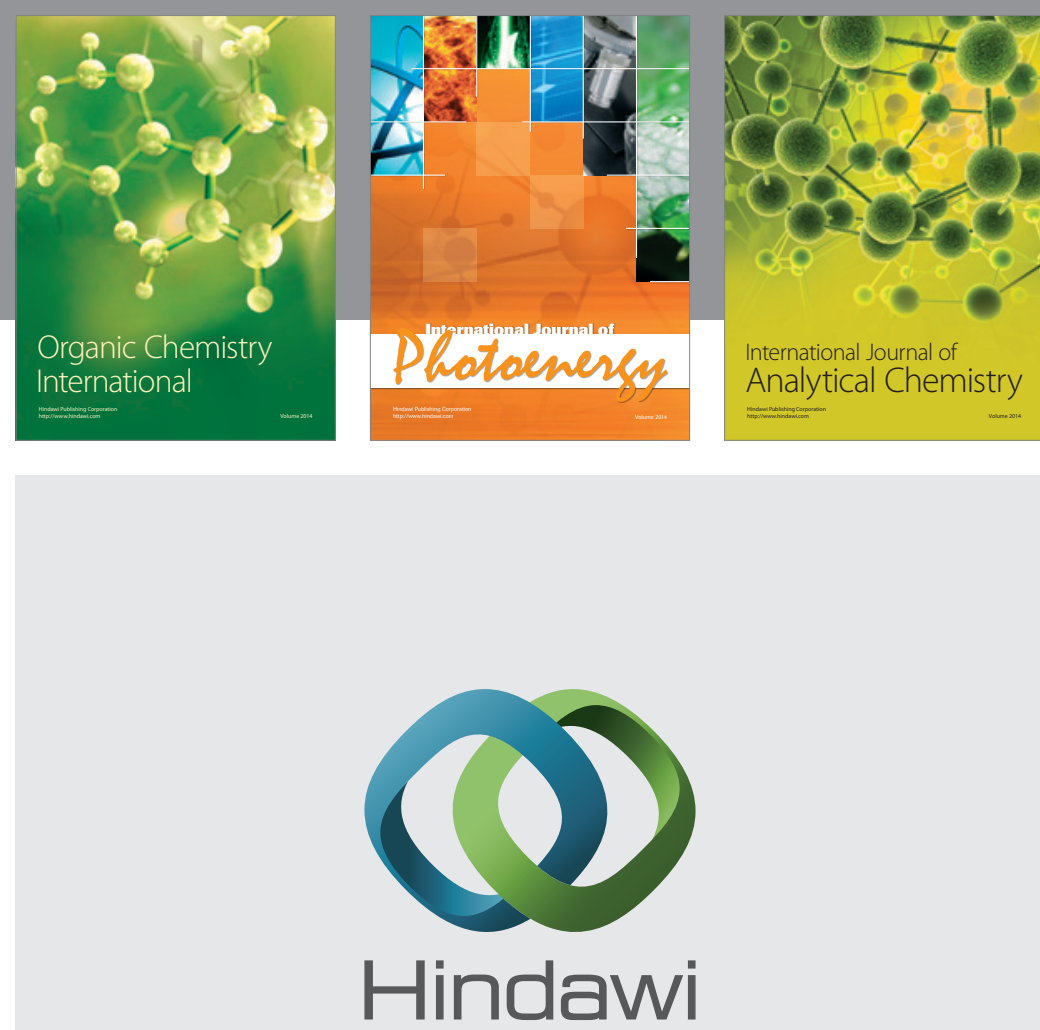

Submit your manuscripts at

http://www.hindawi.com
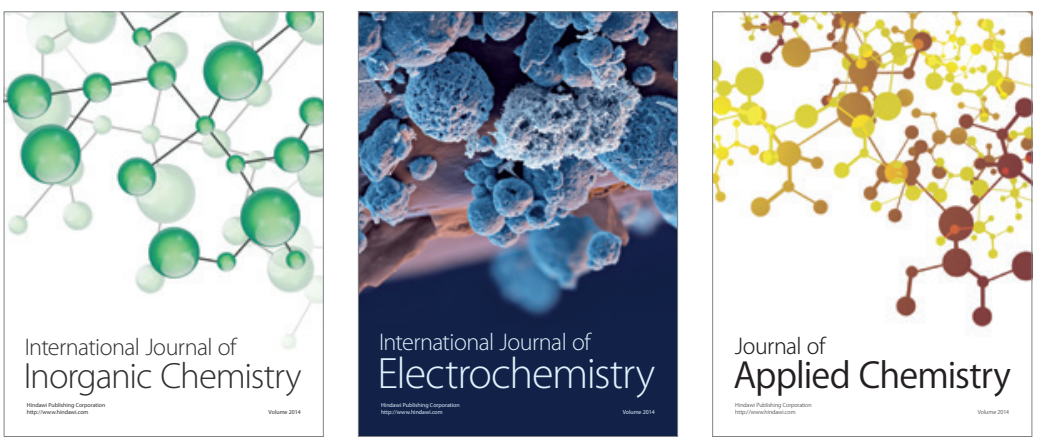

Journal of

Applied Chemistry
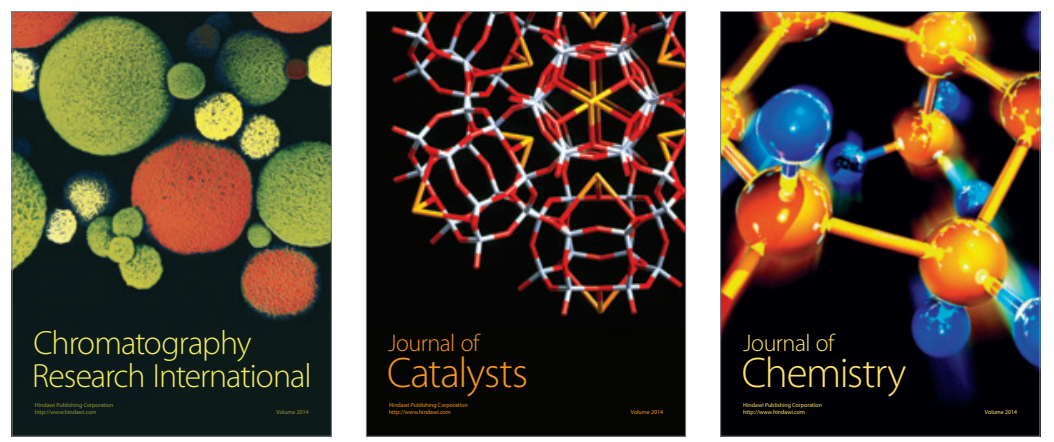
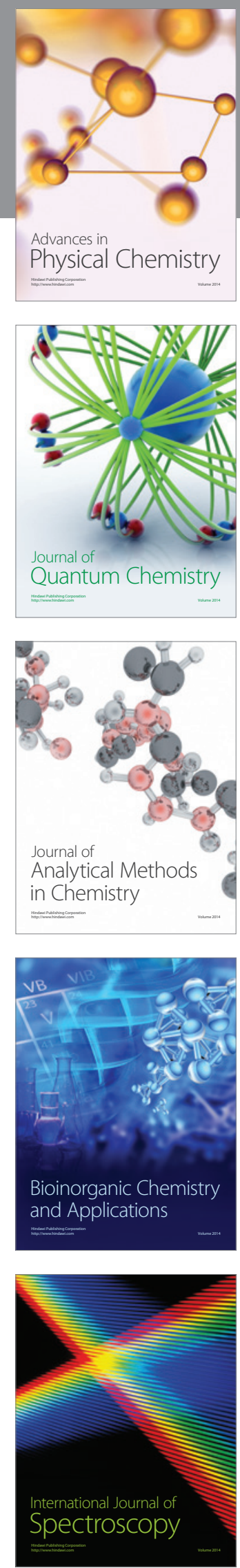